\title{
Seleksi Fitur Support Vector Machine pada Analisis Sentimen Keberlanjutan Pembelajaran Daring
}

Support Vector Machine Feature Selection on Online Learning Sustainability Sentiment Analysis

\author{
Amar P. Natasuwarna \\ Jurusan Sistem Informasi, STMIK Pontianak \\ e-mail: a.pegirosa@gmail.com
}

\begin{abstract}
Abstrak
Pernyataan Mendikbud Republik Indonesia mengenai keberlanjutan pembelajaran daring memperoleh komentar positif dan negatif dari masyarakat melalui Twitter. Tweet atau komentar masyarakat berbahasa Indonesia melalui Twitter diambil secara crawling. Komentar tersebut merupakan opini masyarakat yang perlu didengar. Permasalahannya, komentar tersebut sulit dipilah untuk mendapatkan term atau kata hasil dari komentar positif atau negatif sehubungan penggunaan ragam kata yang digunakan diantaranya penggunaan bahasa tidak formal, simbol, singkatan, bahasa asing, dan bahasa daerah. Mengatasi hal tersebut, dilakukan penelitian menggunakan analisis sentimen. Untuk mendapatkan hasil evaluasi terbaik diperlukan perbandingan ideal antara data latih dan data uji. Tahapan penelitian terdiri dari pengambilan data mentah; pre-processing data; seleksi fitur dengan Term Frequency dan TF-IDF; klasifikasi dengan Support Vector Machine (SVM); dan evaluasi menggunakan k-Fold Cross Validation dan Confusion Matrix. Tujuan penelitian adalah melakukan analisis sentimen dengan algoritma SVM membandingkan dua seleksi fitur Term Frequency dan TF-IDF untuk memperoleh nilai $k$-Fold pada k-Fold Cross Validation yang menghasilkan nilai evaluasi tertinggi. Data yang digunakan berjumlah 200 data tweet terdiri dari 100 komentar positif dan 100 komentar negatif menggunakan lima rasio perbandingan data latih dan data uji. Penelitian menghasilkan evaluasi tertinggi pada pada 8-Fold Cross Validation dengan accuracy sebesar $86,00 \%$, precision sebesar $87,38 \%$, dan recall sebesar $85,02 \%$.
\end{abstract}

Kata kunci-SVM, Term Frequency, TF-IDF, Analisis Sentimen, Pembelajaran Daring

\begin{abstract}
The statemen of Education and Culture Minister of Indonesia Repuclic related to continuity of online learning that rises positive and negative comments from the public via Twitter. Tweet using Indonesian language were crawled. The commands were representative of public opinion that need to be listened. The problem was dificult to separated into negative and positive commands. It was because the various of terms that included nonformal language, symbols, abbreviations, foreign language and mother tongue usages. Sentiment analysis could solve its problem. To find the best results, an ideal comparasion between training data and testing data was required. The research method included capturing raw data; pre-processing data; feature selection consisted of Term Frequency and TF-IDF; classification using Vector Machine (SVM); and evaluation that involved k-Fold Cross Validation and Confusion Matrix. The research objective was to conduct a sentiment analysis with the SVM algoritm comparing the two feature selections which were Term Frequency and TF-IDF against the k-Fold variable on Cross Validation to have $k$-Fold on the $k$-Fold Cross Validation which produced the highest evaluation values. The data used were 200 tweets consisting of 100 positive and 100 negative comments using five ratio comparison of training data and testing data. This research obtained the highest score of evaluation at 8-Fold Cross Validation with an accuracy of $86.00 \%$, a precision of $87.38 \%$, and a recall of $85.02 \%$.
\end{abstract}

Keywords-SVM, Term Frequency, TF-IDF, Sentiment Analysis, Online Learning 


\section{PENDAHULUAN}

Menteri Pendidikan dan Kebudayaan Republik Indonesia (Mendikbud), Nadiem Makarim pada hari Kamis tanggal 2 Juli 2020 dalam rapat kerja bersama Komisi X DPR memberikan pernyataan bahwa setelah berakhirnya wabah pandemi Covid-19, pembelajaran jarak jauh atau pembelajaran daring dapat tetap digunakan bersamaan dengan pembelajaran tatap muka atau luring yang disebut dengan model hibrid. Pernyataan tersebut telah memberi pengaruh yang luas pada kalangan masyarakat dengan berbagai komentar melalui media sosial seperti Twitter. Banyak tweet yang dilakukan masyarakat dalam bentuk komentar positif maupun negatif menanggapi pernyataan yang mengarah pada dilanjutkannya pembelajaran daring. Komentarkomentar tersebut dapat dijadikan bahan untuk menyerap aspirasi masyarakat dan menangkap persoalan-persoalan yang ada pada masyarakat. Permasalahannya, komentar-komentar tersebut begitu banyak jumlah ragam kata, singkatan kata, bahasa tidak formal, maupun simbol, sehingga menimbulkan kesulitan ketika harus memilah kata atau kelompok kata yang dapat menghasilkan pernyataan positif ataupun pernyataan negatif [1]. Untuk mengklasifikasi berbagai pernyataan tersebut dapat dilakukan dengan analisis sentimen. Salah satu algoritma yang banyak digunakan pada analisis sentimen diantaranya adalah Support Vector Machine (SVM) [2]. Kelebihan menggunakan algoritma $S V M$ diantaranya adalah dapat menghasilkan akurasi yang baik [2], selain itu algoritma ini mempunyai kemampuan pada data yang berdimensi tinggi yang diperlukan pada analisis sentimen [1].

Analisis sentimen adalah suatu studi yang berhubungan dengan komputasi dikaitkan dengan pendapat, emosi, atau komentar seseorang atau masyarakat ketika memberikan respon terhadap suatu peristiwa yang dapat dinyatakan dengan bentuk teks $[3,4]$. Analisis sentimen mampu mengubah data yang berbentuk tidak terstruktur menjadi data yang terstruktur [3]. Kemanfaatan analisis sentimen itu begitu besar pada berbagai bidang sebagai bahan evaluasi dan ide, sehingga membuat analisis sentimen ini berkembang dengan sangat pesat terutama dalam menanggapi suatu peristiwa, pernyataan ataupun komentar yang menimbulkan kontroversi [5]. Pernyataan Mendikbud mengenai kelanjutan pembelajaran daring paska pandemi Covid-19 menimbulkan pro dan kontra dikalangan masyarakat.

Kehadiran wabah pandemi Coronavirus Diseases 2019 (Covid-19), merubah cara orang berpikir dan melakukan kegiatan sehari-hari. Covid-19 menimbulkan krisis kesehatan di seluruh dunia [6]. WHO pada tanggal 30 Januari 2020, telah menetapkan keadaan darurat kesehatan pada masyarakat di seluruh dunia [7]. Indonesia, tanggal 2 Maret 2020 melaporkan untuk pertama kali telah terjangkit Covid-19 sebanyak 2 orang, dan dua minggu kemudian dilaporkan telah terjangkit menjadi 10 orang [8]. Tanda-tanda gejala umum orang terjangkit Covid-19 diantaranya batuk, demam, dan sesak napas yang akut, dengan masa inkubasi antara 5 hingga 14 hari [8]. Sekolahsekolah pada seluruh jenjang dari tingkat dasar hingga perguruan tinggi di banyak negara ditutup untuk sementara waktu [6]. Keadaan darurat ini, memaksa sebagian besar kegiatan termasuk diantaranya adalah pendidikan dilakukan secara daring [7]. Menurut UNESCO, pembelajaran melalui daring dilakukan supaya 577 juta anak seluruh dunia tetap dapat menjalankan aktivitas belajar [6]. Dengan semakin banyaknya masyarakat Indonesia yang terinfeksi Covid-19, maka pada tanggal 24 Maret 2020, Mendikbud mengeluarkan surat edaran yang berkaitan dengan tata cara pembelajaran selama terjadinya Covid-19, dimana isinya berkaitan dengan pembelajaran jarak jauh atau daring [8].

Tiga bulan setelah surat edaran Mendikbud mengenai pembelajaran menggunakan daring selama pandemi Covid-19, tepatnya tanggal 2 Juli 2020, Mendikbud memberikan pernyataan mengenai pembelajaran daring yang berlanjut meskipun pandemi Covid-19 telah berakhir. Pernyataan Mendikbud ini menjadi kontroversi dengan banyaknya berbagai komentar positif maupun negatif. Sebelum pernyataan dari Mendikbud mengenai pembelajaran daring yang berlanjut, sudah beredar berbagai pendapat para peneliti yang telah menghasilkan pernyataan positif maupun negatif. Berikut adalah pernyataan positif sebelum pernyataan pembelajaran daring oleh Mendikbud. Pertama, pembelajaran daring akibat mewabahnya Covid-19 memaksa 
peserta didik harus segera menguasai teknologi yang berhubungan dengan pembelajaran jarak jauh [6]. Kedua, pembelajaran daring menjadikan para pelaku kegiatan tersebut mempunyai keleluasaan tempat dan waktu yang lebih banyak dibandingkan dengan pembelajaran luring sehingga para pelaku kegiatan ini dapat menentukan kapan tempat dan waktu yang tepat untuk dilakukan proses pembelajaran [7]. Ketiga, pembelajaran daring memungkinkan untuk menyediakan akses bagi semua orang dengan cara yang lebih efektif dan menjadikan peserta didik menjadi lebih mandiri [6,7]. Akses bagi semua orang didukung dengan upaya lembaga pendidikan non formal dapat menjaring sebanyak-banyaknya peserta, dengan menyediakan diskon bagi siapapun yang ingin belajar secara daring [9]. Keempat, sudah banyak sarana teknologi telah dapat mendukung keberlangsungan pembelajaran daring seperti penggunaan Whatapps Group, Google Classroom, dan Zoom [7,8]. Kelima, mulai bermunculan inovasiinovasi cara-cara pengajaran dengan pembelajaran daring untuk meningkatkan motivasi dan minat belajar peserta didik [10]. Sebaliknya, ditemukan pula pendapat negatif mengenai pembelajaran secara daring. Pertama, pembelajaran daring tidak selalu membuat peserta didik mengalami keberhasilan, ada beberapa faktor yang mempengaruhi seperti suasana rumah dan karakteristik dari peserta didik itu sendiri [8]. Kesulitan yang dialami peserta didik terutama yang masih pada tingkat pendidikan dasar adalah tidak selalu ada pendamping di rumah sehubungan dengan orang tua yang bekerja, selain itu masih banyak juga orang tua yang masih gagap teknologi [8]. Kedua, pada kenyataannya, tidak semua pembelajaran dapat dilakukan secara daring [7]. Sebagai contoh, pembelajaran yang memerlukan praktek keterampilan dimana sarana yang digunakan hanya ada di sekolah atau di lapangan. Ketiga, pembelajaran daring membuat peserta didik atau orang tua harus mengeluarkan biaya ekstra dengan membeli tambahan kuota $[8,10]$. Sehingga perlu dipikirkan untuk dapat menggunakan aplikasi ringan yang menyedot kuota rendah atau cara lain bekerja sama dengan provider untuk menyediakan kuota gratis [11]. Keempat, pembelajaran daring membuat aktifitas peserta didik terutama bagi yang masih berusia anak-anak untuk bersosialisasi seperti bermain dan bersenda gurau dengan teman-temannya sebayanya di sekolah menjadi berkurang [8]. Kelima, merujuk pada luasnya wilayah Indonesia, pembelajaran daring tidak serta merta dapat dilaksanakan dengan mudah terutama untuk wilayah peserta didik yang tidak terjangkau oleh sinyal selular dan internet yang lemah [10]. Untuk mendapatkan pendapat positif atau negatif setelah pernyataan dari Mendikbud, dapat diperoleh melalui tweet yang dilakukan oleh masyarakat pada media sosial Twitter.

Twitter dikenal sebagai media sosial popular yang banyak digunakan oleh masyarakat untuk mengungkapkan segala macam ide, komentar, keluhan berkaitan dengan kondisi yang ada pada saat ini $[4,12]$. Bagi masyarakat, pengoperasian Twitter seperti melakukan tweet yang berisi komentar-komentar dapat dilakukan dengan mudah [13]. Namun untuk melakukan analisis pada komentar-komentar berupa tweet, Twitter mempunyai persoalan dengan format $85 \%$ teks yang tidak terstruktur, ditambah lagi dengan penggunaan singkatan dan bahasa yang tidak formal $[3,5]$. Keberadaan analisis sentimen, mengatasi persoalan-persoalan tersebut dengan cara merubah format yang tidak terstruktur menjadi format yang terstruktur dan terklasifikasi [14]. Komentarkomentar masyarakat melalui Twitter merupakan sumber data yang diakui validitasnya dalam melakukan analisis sentimen [15].

Penelitian analisis sentimen dengan menggunakan algoritma SVM sudah banyak dilakukan. Penelitian yang dimaksud, diantaranya adalah analisis sentimen yang berkaitan dengan kepuasan pelanggan pada rumah makan [1], analisis sentimen yang berhubungan dengan evaluasi penggunaan ruangguru [2], dan analisis sentimen penilaian acara televisi [16].

Merujuk pada penelitian sebelumnya tersebut di atas, penelitian ini mempunyai kesamaan pada analisis sentimen dan algoritma $S V M$, perbedaannya penelitian ini bersama perbandingan seleksi fitur, dikhususkan memperoleh $k$-Fold Cross Validation pada nilai evaluasi tertinggi. Tujuan penelitian adalah melakukan analisis sentimen dengan algoritma SVM membandingkan dua seleksi fitur Term Frequency dan $T F-I D F$ sehingga diperoleh nilai $k$-Fold pada $k$-Fold Cross Validation, untuk hasil nilai evaluasi tertinggi. Data diambil dari komentar masyarakat melalui media sosial Twitter berupa komentar positif atau komentar negatif berkaitan pernyataan Mendikbud mengenai keberlanjutan pembelajaran daring tanggal 2 Juli 2020 dalam rapat kerja 
bersama Komisi X DPR, dengan menggunakan algoritma $S V M$ beserta dua seleksi fitur yakni Term Frequency dan TF-IDF [17]. Pada penelitian ini dilakukan analisis komentar terdiri dari dua kelas yaitu komentar positif dan komentar negatif [18]. Data diperoleh melalui Twitter, dengan 100 tweet komentar positif dan 100 tweet komentar negatif [19]. Untuk mempermudah melakukan analisis sentimen, digunakan perangkat lunak RapidMiner yang merupakan salah satu perangkat lunak yang handal [17]. Pada penelitian ini, RapidMiner melakukan pengolahan dengan algoritma SVM, seleksi fitur Term Frequency dan TF-IDF, dan evaluasi dengan dipergunakannya $k$-Fold Cross Validation dan Confusion Matrix [3]. Hasil akhir penelitian yang diharapkan adalah nilai $k$ Fold pada Cross Validation untuk accuracy, precision, dan recall tertinggi, dari 5 rasio pada perbandingan data latih dan data uji. Kelima rasio yang dimaksud termasuk rasio 180:20, 175:25, 160:40, 150:50, dan rasio 100:100 yang dapat dilakukan dengan menggunakan $k$-Fold Cross Validation [1].

\section{METODE PENELITIAN}

Ada lima langkah untuk memperoleh analisis sentimen pada penelitian ini yakni memperoleh sekumpulan data dengan cara raw data capturing, pre-processing, feature selection, classification, dan evaluation [13,20]. Gambar 1 menunjukkan lima langkah yang dilakukan untuk memperoleh analisis sentimen.

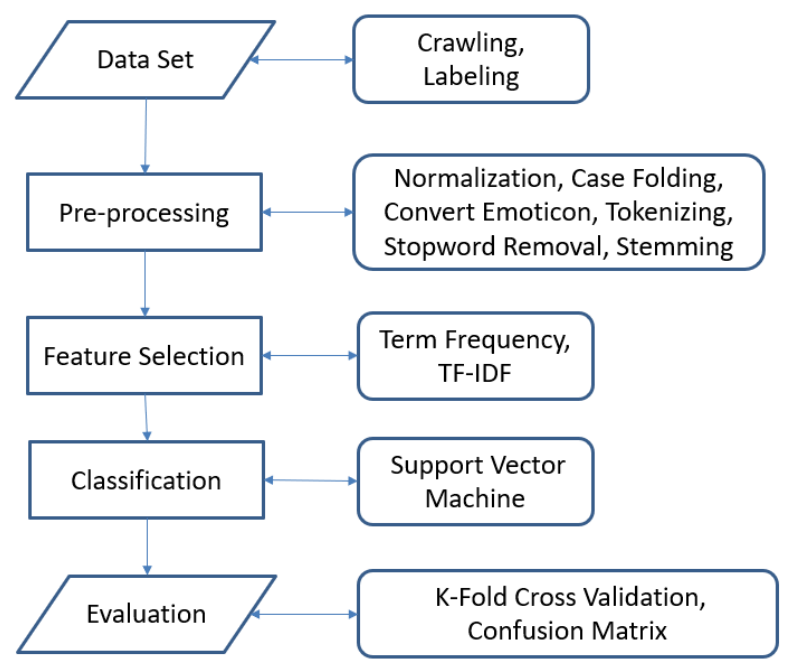

Gambar 1. Langkah-langkah Analisis Sentimen [13,20,21]

Melakukan mengambil data dengan cara crawling sebagai langkah pertama adalah hal yang paling esensial pada analisis sentimen untuk memperoleh data dari komentar-komentar masyarakat yang ada di Twitter. Pada penelitian ini crawling menggunakan aplikasi RapidMiner versi 9.72 dengan mengaktifkan operator Search Twitter.

Langkah kedua adalah melakukan pre-processing sebagaimana lazimnya ketika melakukan pengolahan data mining. Berbeda dengan pre-processing pada data mining umumnya, pada analisis sentimen ini, langkah-langkah yang dapat dilakukan diantaranya dengan melakukan normalization, case folding, convert emoticon, tokenizing, stopword removal, dan stemming [20]. Normalization adalah mentransformasikan istilah kata dari bahasa gaul, bahasa slang, singkatansingkatan kata menjadi istilah baku sesuai dengan KBBI [12]. Normalization juga menghilangkan karakter khusus seperti tanda @, hastag, RT, URL [12]. Karakter-karakter khusus ini tidak mempengaruhi proses pengolahan analisis sentimen. Istilah berikutnya adalah case folding, dimana pada proses ini seluruh huruf dirubah menjadi huruf kecil [13]. Sementara itu, convert emoticon merubah gambar ikon menjadi kata-kata, sebagai contoh, ikon terseyum menjadi eterseyum. Apabila emoticon mengganggu proses analisis sentimen, emoticon ini dapat diabaikan 
[12]. Tokenizing memecah sekumpulan kata menjadi setiap kata, selain itu, tokenizing meniadakan karakter titik, koma, spasi, angka, dan garis miring [13]. Stopword removal artinya kegiatan meniadakan semua kata yang tidak relevan dengan proses klasifikasi [21]. Istilah terakhir pada kegiatan pre-processing adalah stemming, dimana fungsinya adalah mengembalikan setiap kata hanya menjadi kata dasarnya saja [21], sebagai contoh bepergian menjadi pergi, memaksakan menjadi paksa.

Tahap pre-processing dilalui, maka dilanjutkan tahap ketiga yang disebut feature selection atau seleksi fitur. Pada tahap ini, kata atau bisa juga disebut dengan istilah atau term dilakukan pembobotan untuk memperoleh suatu nilai [21]. Selesainya tahap pre-processing masih menyisakan jumlah atribut yang besar, apabila itu terjadi, maka akan mengurangi kinerja dari proses klasifikasi yang berdampak pada tingkat akurasi yang rendah [1]. Seleksi Fitur bertugas melakukan proses mengurangi fitur yang dianggap tidak relevan, caranya dengan melakukan eliminasi pada atribut yang tidak relevan tersebut [1]. Seleksi Fitur yang digunakan adalah Term Frequency dan TF-IDF [22]. Term Frequency berfungsi untuk mengetahui jumlah kemunculan kata pada suatu dokumen [17]. Jika kemunculan suatu kata atau term semakin besar maka bobot nilai akan semakin besar [20]. Persamaan (1) menunjukkan Term Frequency.

$$
\mathrm{w}_{\mathrm{tf}} \mathrm{t,d}= \begin{cases}1+\log _{10} \mathrm{tf}_{\mathrm{t}, \mathrm{d}}, & \text { if } \mathrm{tf}_{\mathrm{t}, \mathrm{d}}>0 \\ 0, & \text { otherwise }\end{cases}
$$

Diketahui $t f$ merupakan Term Frequency, Wtf menyatakan bobot tf yang dihitung berdasarkan logaritma [23].

TF-IDF (Term Frequency Inverse Document Frequency) adalah salah satu metode untuk pembobotan, dimulai dari terjadinya perubahan suatu text atau data menjadi text berupa vector banyak dimension [24]. Bobot $T F-I D F$ adalah bobot setiap kata atau term untuk tiap dokumen. Berbeda dengan Term Frequency, pada TF-IDF, kata yang jarang muncul pada dokumendokumen yang ada, justru mempunyai suatu bobot Inverse Document Frequency yang cukup tinggi [24]. Persamaan (2) menunjukkan TF-IDF.

$$
w_{t, d}=w_{t f_{t, d}} \times i d f_{t}
$$

Diketahui Wtf merupakan pembobotan Term Frequency, sedangkan idf merupakan bobot kebalikan dari bobot dokument frequency.

Langkah keempat adalah klasifikasi dengan menggunakan SVM. Algoritma SVM mempunyai kemampuan menganalisis data dan melakukan pengenalan pola [12]. SVM sangat baik digunakan untuk keperluan text mining [25]. SVM sangat sesuai digunakan untuk melakukan klasifikasi dua kelas [1]. SVM melakukan pekerjaannya dengan melakukan pencaharian hyperline terbaik, dimana yang dimaksud dengan hyperline adalah garis pemisah diantara dua kelas [1]. Semakin besar margin atau garis pemisah maka semakin kecil tingkat kesalahan klasifikasi yang terjadi [24]. Gambar 2 berikut di bawah ini menunjukkan perbedaan antara perolehan hyperline dengan margin kecil dan hyperline dengan margin besar.
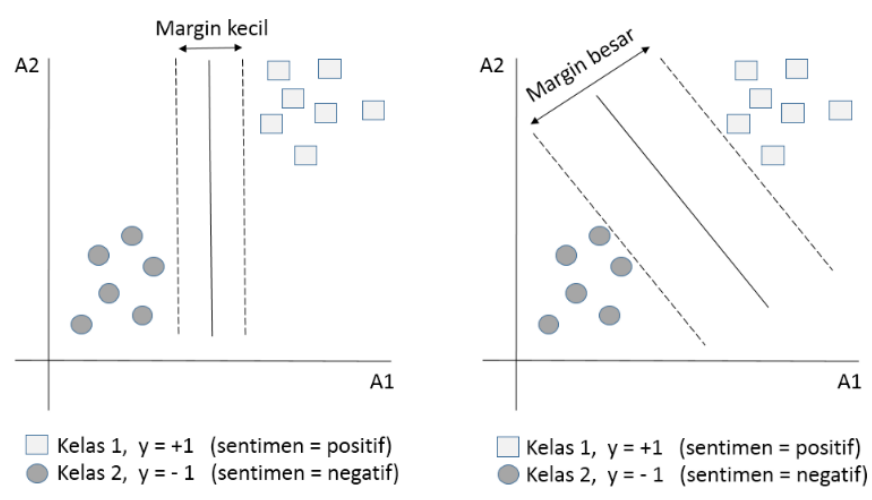

Gambar 2. Margin Lebih Besar Akurasi Lebih Baik [26] 
Evaluasi merupakan langkah terakhir dari serangkaian langkah analisis sentimen. Evaluasi mengukur kualitas dari semua proses yang telah dijalankan sebelumnya [25]. Pada penelitian ini dilakukan evaluasi perbandingan antara akurasi yang dihasilkan dengan menggunakan seleksi fitur Term Frequency dan TF-IDF [1]. Evaluasi yang dilakukan menggunakan kemampuan $k$-Fold Cross Validation dan Confusion Matrix. Evaluasi dimulai dari $k$-Fold Cross Validation. Pada $k$-Fold Cross Validation, sekumpulan data dalam bentuk data latih terbagi atas k himpunan data yang dilakukan secara acak dengan komposisi sama, dimana salah satu kelompok tersebut menjadi data uji. Berikutnya, iterasi dilaksanakan sebanyak $k$-Fold [12]. Sebagai contoh jika $k$-Fold $=5$, maka 5-Fold Cross Validation menjadi seperti Gambar 3 berikut ini.

\begin{tabular}{|c|l|l|l|l|l|}
\hline Pengujian & \multicolumn{5}{|c|}{ Data Set } \\
\hline 1 & Data Uji & & & & \\
\hline 2 & & Data Uji & & & \\
\hline 3 & & & Data Uji & & \\
\hline 4 & & & & Data Uji & \\
\hline 5 & & & & & Data Uji \\
\hline
\end{tabular}

Gambar 3. Contoh 5-Fold Cross Validation [12]

Dengan jumlah data adalah 200, maka untuk 5-Fold Cross Validation, data akan dikelompokkan menjadi 5, dimana masing-masing kelompok berisi 40 data. Pada pengujian 1, 40 data pertama sebagai data uji, selebihnya sebagai data latih. Pada pengujian 2, 40 data kelompok kedua sebagai data uji, selebihnya sebagai data latih. Hingga pada pengujian 5, 40 data kelompok lima sebagai data uji dan selebihnya sebagai data latih.

Selesai Cross Validation dilanjutkan dengan Confusion Matrix. Tabel 1 tersebut di bawah ini merupakan tabel Confusion Matrix yang dibagi atas aktual positif, aktual negatif, prediksi positif, dan prediksi negatif.

Tabel 1. Confusion Matrix [4,12]

\begin{tabular}{|c|l|c|c|}
\hline \multicolumn{2}{|c|}{} & \multicolumn{2}{c|}{ Prediksi } \\
\cline { 3 - 4 } Aktual & Negatif & a & P \\
\cline { 2 - 4 } & Positif & c & d \\
\hline
\end{tabular}

Dari Tabel 1 di atas, simbol a menyatakan jumlah prediksi benar bahwa data menyatakan negatif. Simbul b menunjukkan jumlah prediksi keliru untuk menyatakan data positif. Simbul c memperlihatkan jumlah prediksi keliru untuk menyatakan data positif. Simbul d adalah jumlah prediksi untuk menyatakan data positif. Nilai-nilai hasil evalusi dari accuracy, precision dan recall pada confusion matrix diturunkan dan dihitung dari komponen-komponen tersebut [25].

\section{HASIL DAN PEMBAHASAN}

Pengambilan data yang diperoleh dari Twitter dilakukan antara tanggal 5 hingga 14 Juli 2020. Data diambil mulai dari tiga hari setelah pernyataan Mendikbud mengenai kelanjutan pembelajaran daring setelah usai masa pandemi Covid-19. Data tersebut kemudian digunakan untuk melakukan analisis sentimen. Pengujian memanfaatkan algoritma $S V M$ dapat diketahui melalui cara pengukuran dengan accuracy, precision, dan recall. Kata kunci "belajar daring", "belajar online", dan "belajar jarak jauh" digunakan untuk mengambil data dari komentar masyarakat melalui tweet. Ada 200 tweet komentar masyarakat yang terdiri dari 100 tweet sentimen positif dan 100 tweet sentimen negatif yang digunakan untuk keperluan analisis sentimen. 
Pengambilan data yang tersimpan di dalam database Twitter menggunakan aplikasi RapidMiner. Sebagai aplikasi penerapan data science dan machine learning, kenyataannya RapidMiner tidak mempunyai fitur untuk mengambil data dari Twitter. Supaya RapidMiner dapat melakukan pengambilan data dari Twitter, RapidMiner menyediakan fitur untuk memperoleh fungsi tersebut dari marketplace. Fungsi yang dapat diambil tersebut adalah Web Mining 9.3.1. Fungsi ini menghadirkan operator Search Twitter yang dapat mengkoneksikan dengan Twitter Search API. Data yang telah diperoleh dapat disimpan dengan berbagai format, termasuk format Microsoft Excel yang akan digunakan pada penelitian ini. Tabel 2 berikut di bawah ini menunjukkan contoh tweet yang berhasil diambil dari aplikasi RapidMiner. Secara manual, data tersebut ditambahkan atribut atau label dengan nilai positif atau nilai negatif.

Tabel 2. Contoh Data Tweet Komentar Masyarakat

\begin{tabular}{|c|l|c|}
\hline No & Tweet & Sentimen \\
\hline 1 & $\begin{array}{l}\text { Belajar Daring, Siswa Miskin Rentan Tertinggal Materi } \\
\text { Pelajaran https://t.co/IpEz8HCjaY }\end{array}$ & Negatif \\
\hline 2 & $\begin{array}{l}\text { Klo yg ngeluh "aku kuliah online makin bodoh". Apa tdk } \\
\text { pernah belajar sendiri? Klo nda tau kan bisa nanya dosen, temen } \\
\text { pun kau ada, tgl vc/call, text pun no prob. Pasti ada cara lah } \\
\text { anda belajar. Lagian, mahasiswa udh ga masanya didikte sma } \\
\text { pengajar, namanya aja Maha, dah gede. }\end{array}$ & Positif \\
\hline
\end{tabular}

Gambar 4 di bawah ini menunjukkan kata sentimen positif hasil seleksi fitur dengan menggunakan Term Frequency. Dimana, 3 besar kata berdasarkan seleksi fitur dengan Term Frequency adalah gratis, mandiri, diskon dan waktu, kemudian diikuti oleh tetap, bantu, teknologi, semangat, baru, hemat, mantap, tanya, aplikasi, kreatif, pjj, dan populer.

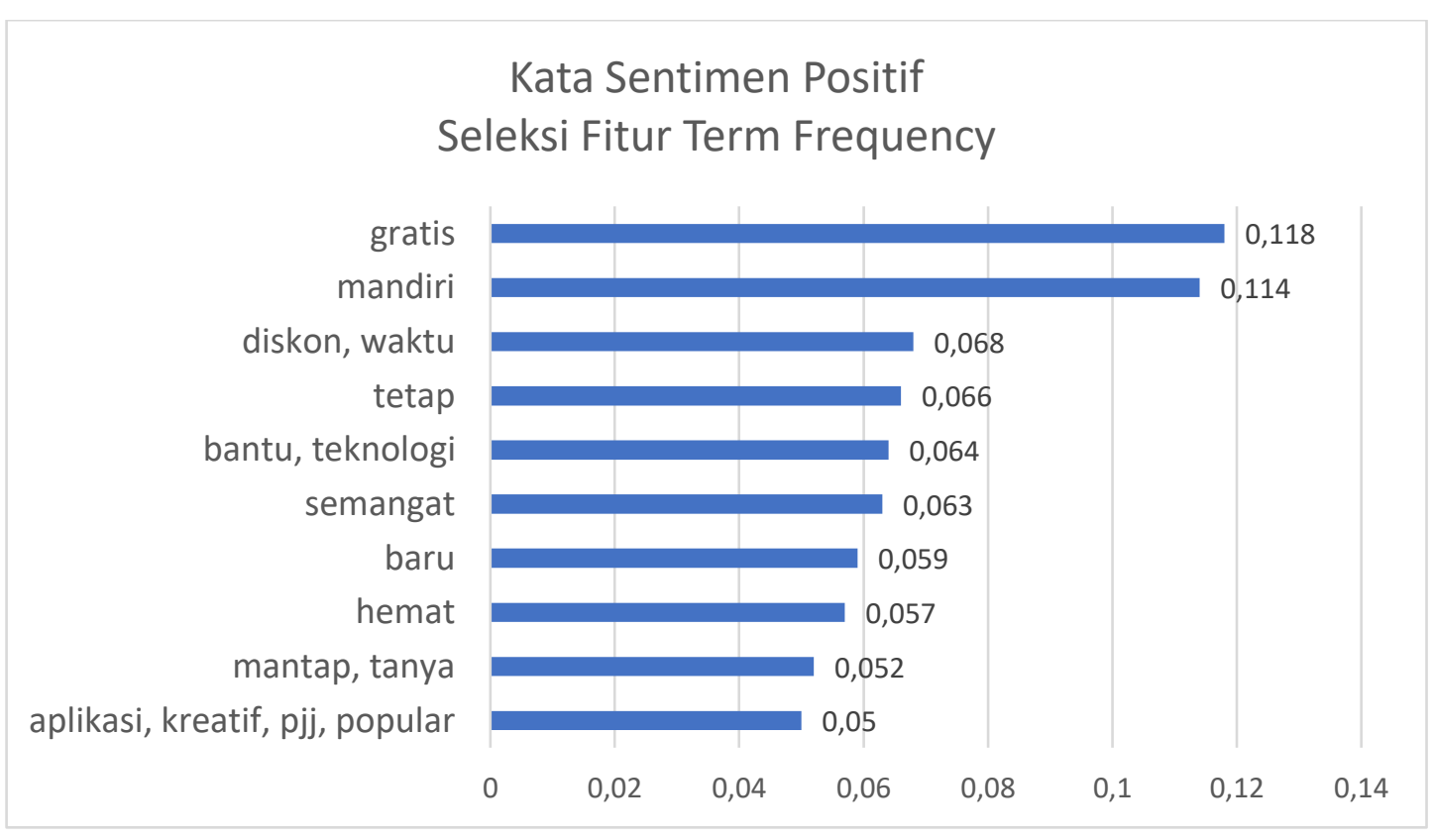

Gambar 4. Grafik 10 Besar Kata Sentimen Positif Berdasarkan Seleksi Fitur Term Frequency

Berikut ini pembahasan mengenai 3 besar kata berdasarkan seleksi fitur yang terdapat pada Gambar 4. Bahasan yang dimaksud diambil berdasarkan tweet yang dilakukan masyarakat dibandingkan dengan opini dari hasil penelitian yang sudah dipublikasikan sebelum pernyataan dari Mendikbud. Pada sentimen positif, makna kata gratis pada grafik di bawah yang dimaknai oleh masyarakat dan hasil penelitian [11] adalah berkaitan dengan fasilitas pemerintah yang bekerja sama dengan operator selular untuk memberi fasilitas gratis kepada peserta didik 
penggunaan pulsa pada situs tempat sarana belajar. Kata mandiri, sebagaimana pada tweet dan hasil penelitian [7], berhubungan dengan keadaan yang memaksa pelajar dan mahasiswa harus banyak belajar lebih mandiri. Makna diskon dari tweet dan hasil penelitian [9] adalah banyaknya pelatihan termasuk juga bimbingan belajar yang memberikan diskon selama pandemik. Makna waktu menyangkut banyaknya waktu yang dihemat dengan pembelajaran jarak jauh, tidak perlu berkendaraan mencapai tempat belajar. Kelebihan waktu itu dapat digunakan untuk belajar banyak hal di luar pendidikan formal seperti membuat kue, membuat konten video dan banyak lagi. Sementara hasil penelitian memaknai keuntungan waktu sebagai suatu banyak pilihan waktu dan tempat terjadinya proses belajar [7].

Gambar 5 di bawah ini menunjukkan hasil seleksi fitur kata sentimen negatif dengan menggunakan Term Frequency. Ada 3 besar kata berdasarkan seleksi fitur tertinggi yakni permanen, hp, dan sosialisasi diikuti oleh tugas, susah, sulit, bosan, biaya, sinyal, bodoh, kurang, akses, dan mudah.

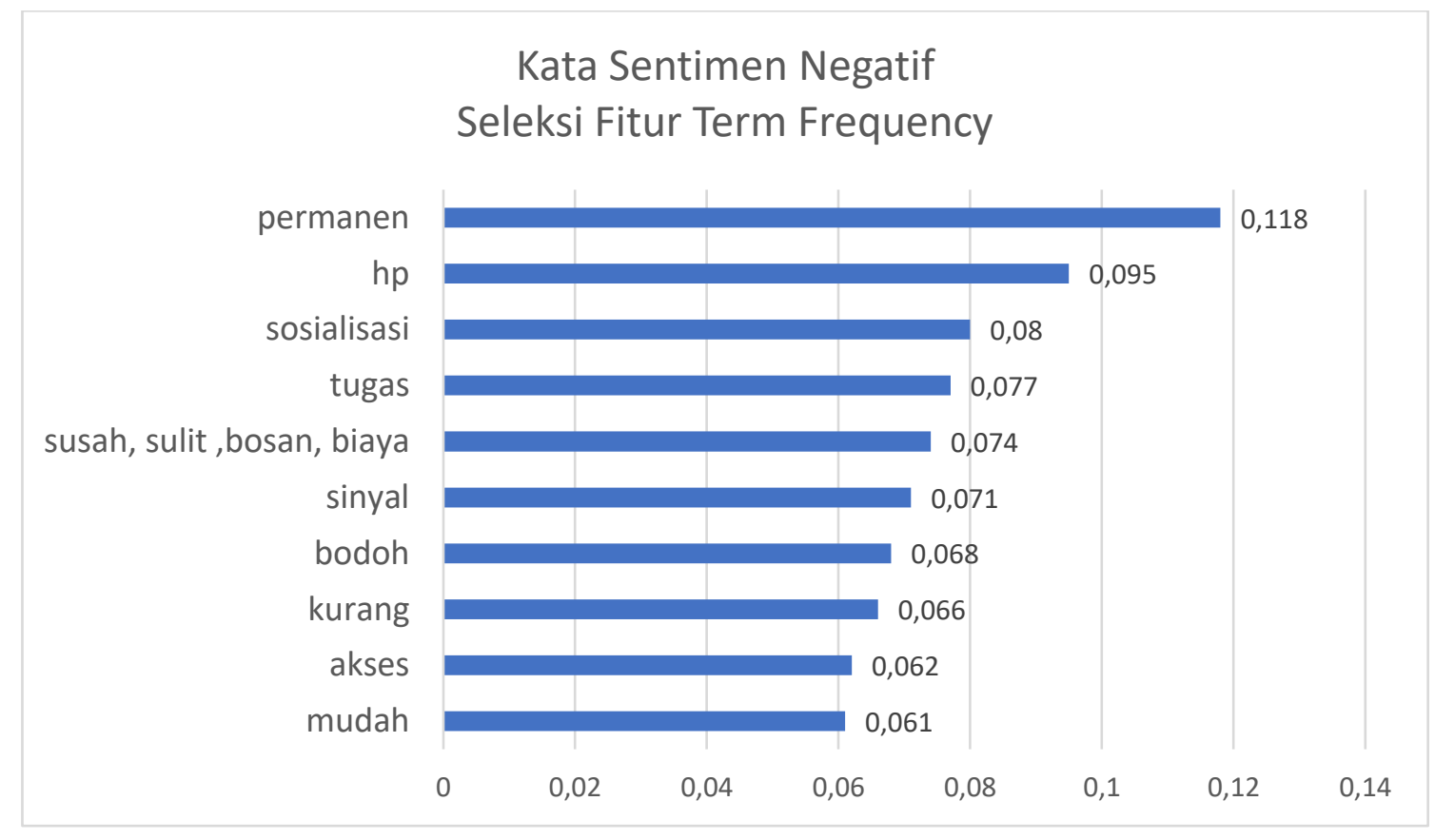

Gambar 5. Grafik 10 Besar Kata Sentimen Negatif Berdasarkan Seleksi Fitur Term Frequency

Seperti pada Gambar 5, pada sentimen negatif menurut seleksi fitur Term Frequency, permanen menempati peringkat pertama. Permanen mengandung makna bahwa masyarakat yang disampaikan melalui Twitter tidak menghendaki pembelajaran secara daring dilakukan secara berkelanjutan paska Covid-19. Keberatan pembelajaran daring secara permanen dari tweet dan hasil penelitian, walaupun pada penelitian tidak secara eksplisit menyebut istilah permanen, diantaranya biaya untuk pendidikan semakin meningkat [10], masih banyak wilayah di Indonesia yang sulit sinyal internet [10], anak-anak tidak dapat bermain dengan teman-teman sekolahnya [8], dan suasana rumah yang tidak mendukung [8]. Kata $h p$ berhubungan dengan keluhan orang tua yang tidak mempunyai $h p$ yang dapat digunakan untuk sekolah daring. Sehingga memaksa orang tua untuk membeli $h p$ yang dapat digunakan untuk keperluan daring, jika tidak, anaknya tidak dapat bersekolah seperti anak lainnya. Mengenai $h p$ ini dapat disamakan dengan hal yang berkaitan dengan pengeluaran biaya ekstra $[8,10]$. Sosialisasi bermakna menurut tweet masyarakat betapa peserta didik berkurang kegiatan untuk berjumpa dan bermain dengan temanteman sekolahnya. Seperti juga yang disampaikan dari hasil penelitian, bahwa sekolah daring terutama untuk anak-anak akan berkurang mereka untuk bermain dan bersenda gurau [8]. 
Gambar 6 di bawah ini menunjukkan hasil 3 kata seleksi fitur tertinggi dengan menggunakan TF-IDF yakni kata gratis, mandiri, dan waktu diikuti dengan tetap, bantu, diskon, teknologi, semangat, baru, hemat, tanya, dan mantap.

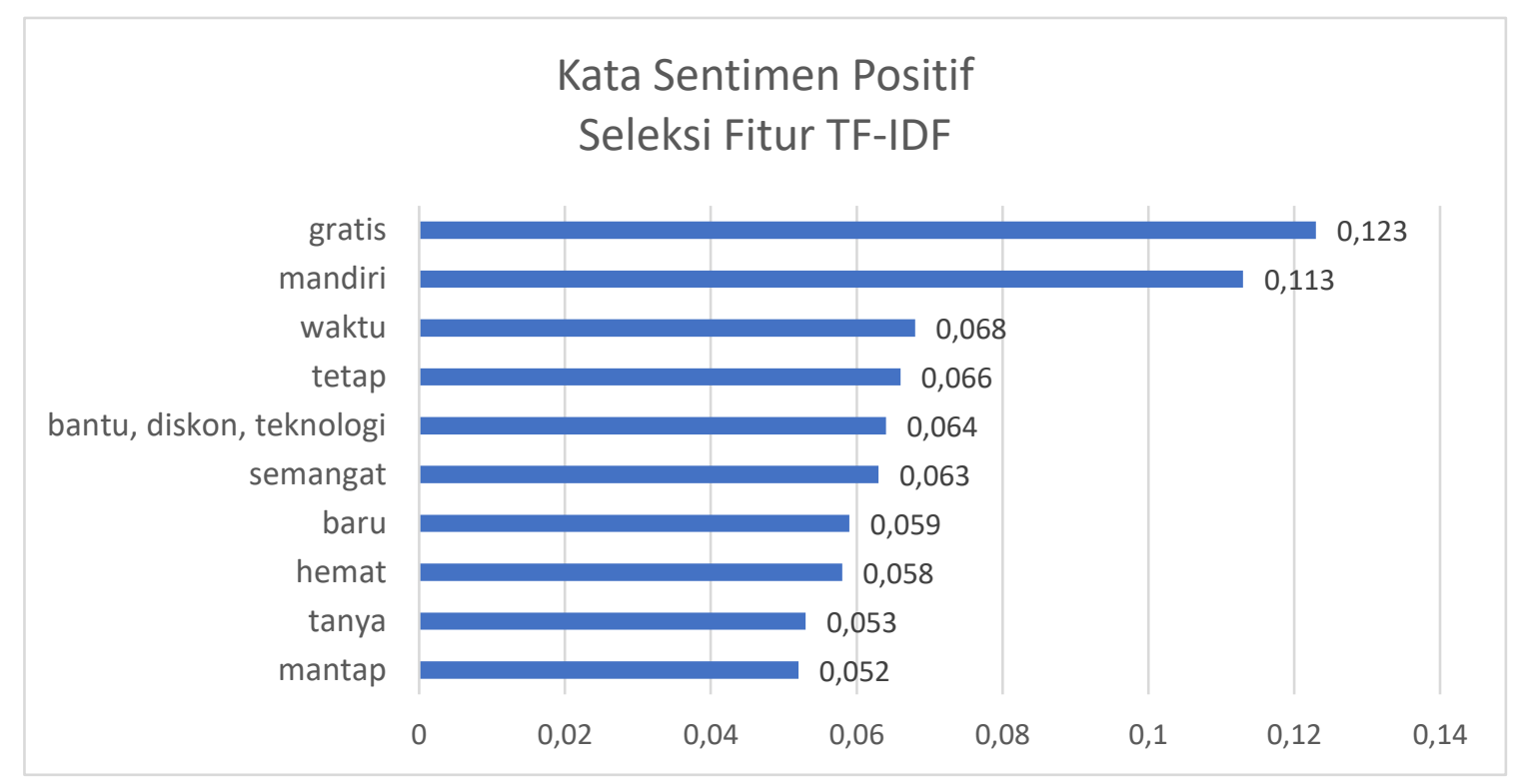

Gambar 6. Grafik 10 Besar Kata Sentimen Positif Berdasarkan Seleksi Fitur TF-IDF

Ada kesamaan antara hasil dari kata sentimen positif seleksi fitur Term Frequency pada Gambar 4 dan sentimen positif seleksi fitur TF-IDF. Pembahasan mengenai 3 besar kata dengan seleksi fitur tertinggi yang terdapat pada Gambar 6 yakni gratis, mandiri, dan waktu telah dijelaskan ketika menerangkan kata dari Gambar 4. Hanya kata diskon pada seleksi fitur Term Frequency yang tidak termasuk pada kata 3 besar pada seleksi fitur TF-IDF.

Gambar 7 di bawah ini menunjukkan hasil seleksi fitur kata sentimen negatif dengan menggunakan TF-IDF. Ada 3 besar kata dengan bobot tertinggi yakni permanan, hp, biaya dan sosialisasi diikuti oleh sulit, susah, bosan, tugas, bodoh, kurang, dan sinyal.

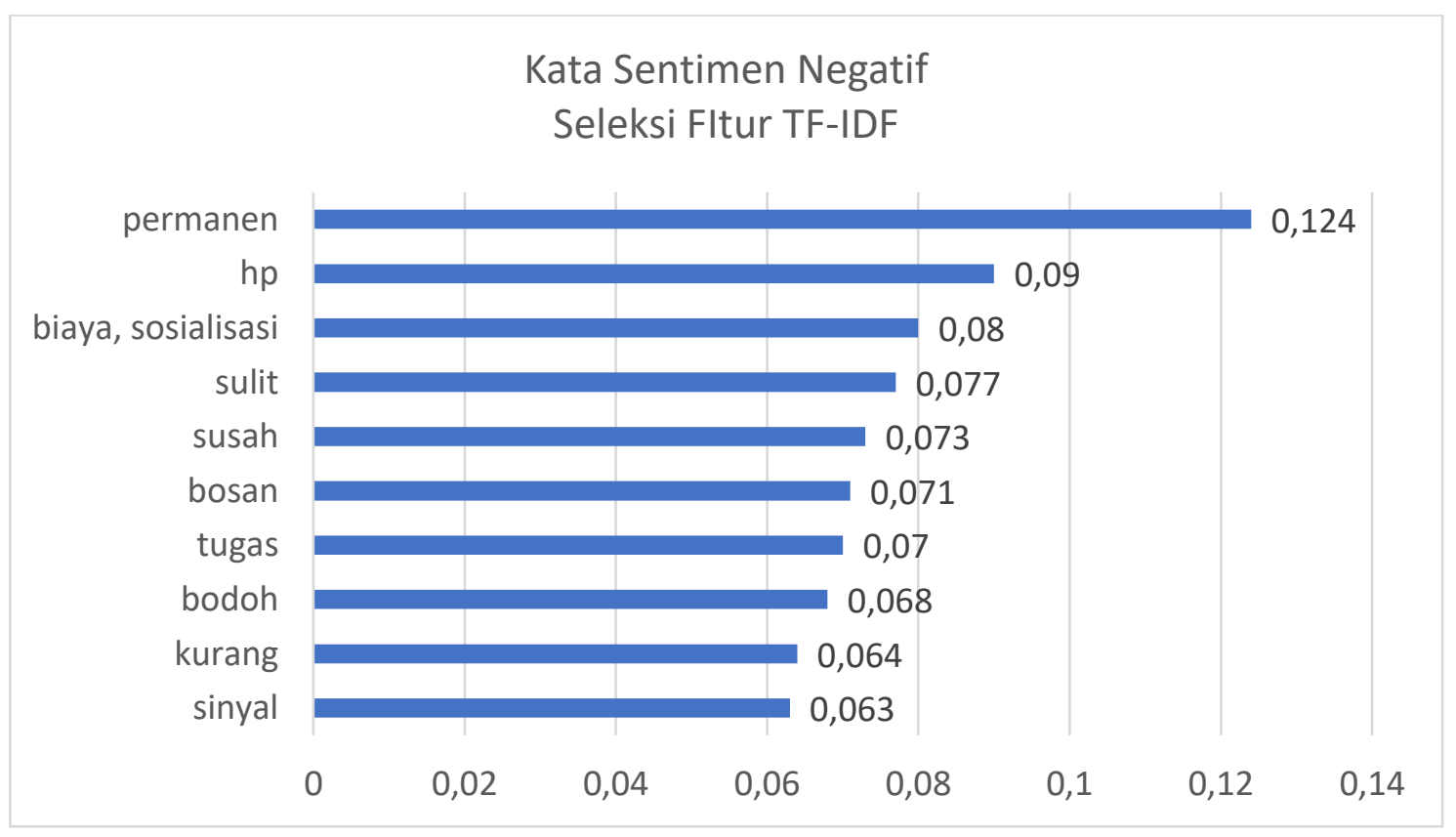

Gambar 7. Grafik 10 Besar Kata Sentimen Negatif Berdasarkan Seleksi Fitur TF-IDF 
Seperti pada Gambar 7. Tiga besar kata yakni permanen, hp, dan sosialisasi telah dijelaskan pada pembahasan kata sentimen negatif seleksi fitur Term Frequency dengan hasil yang diperoleh sama yakni permanen, hp, dan sosialisasi. Tambahan kata biaya yang masuk 3 kata sentimen negatif berdasarkan seleksi fitur $T F-I D F$. Biaya menurut dari tweet masyarakat selain biaya sekolah tidak berkurang, ditambah dengan biaya membeli kuota. Penelitian sebelumnya juga mengingatkan persoalan biaya pada pembelajaran daring bahwa orang tua harus mengeluarkan biaya ekstra terutama untuk membeli kuota $[8,10]$.

Evaluasi penggunaan algoritma SVM didukung dua seleksi fitur yakni Term Frequency dan $T F-I D F$, serta variabel $k$-Fold Cross Validation. Jumlah tweet yang diambil adalah 200 sampel, maka k yang memungkinkan supaya tidak menimbulkan pecahan untuk 5 kali percobaan adalah: 2, 4, 5, 8, dan 10 .

Tabel 3. Hasil Evaluasi berdasarkan Seleksi Fitur Term Frequency

\begin{tabular}{|c|c|c|c|c|c|}
\hline $\begin{array}{c}\text { k- } \\
\text { Fold }\end{array}$ & Data Latih & Data Uji & Accuracy & Precision & Recall \\
\hline 2 & 100 & 100 & $80,00 \%$ & $79,06 \%$ & $83,00 \%$ \\
\hline 4 & 150 & 50 & $83,50 \%$ & $85,45 \%$ & $81,00 \%$ \\
\hline 5 & 160 & 40 & $84,00 \%$ & $86,86 \%$ & $81,00 \%$ \\
\hline 8 & 175 & 25 & $86,00 \%$ & $87,31 \%$ & $85,02 \%$ \\
\hline 10 & 180 & 20 & $86,00 \%$ & $86,64 \%$ & $83,00 \%$ \\
\hline & \multicolumn{2}{|c|}{ Rata-rata } & $83,90 \%$ & $85,06 \%$ & $82,60 \%$ \\
\hline
\end{tabular}

Tabel 3 menunjukkan bahwa kenaikan $k$-Fold pada $k$-Fold Cross Validation berpengaruh kepada kenaikan accuracy dan precision, dari $k$-Fold $=2$ menuju $k$-Fold $=8$. Selanjutnya pada $k$ Fold $=10$ accuracy nilainya tetap dari sebelumnya dan precision nilanya mengalami penurunan. Khusus recall terjadi penurunan dari $k$-Fold $=1$ menuju $k$-Fold $=2$, setelah itu sempat mengalami nilai tetap hingga $k$-Fold $=5$, kemudian mengalami kenaikan pada $k$-Fold $=8$, terakhir mengalami penurunan pada $k$-Fold $=10$. Accuracy tertinggi yakni $86,00 \%$ terjadi pada $k$-Fold $=8$ dan $k$-Fold $=10$. Precision tertinggi sebesar $87,31 \%$ terjadi pada $k$-Fold $=8$. Sedangkan, recall tertinggi sebesar $85,02 \%$ terjadi pada $k$-Fold $=8$. Nilai rata-rata yang didapatkan untuk seleksi fitur pada Term Frequency adalah sebagai berikut: accuracy $=83,90 \%$, precision $=85,06 \%$, dan recall $=$ $82,60 \%$.

Tabel 4. Hasil Evaluasi berdasarkan Seleksi Fitur $T F-I D F$

\begin{tabular}{|c|c|c|c|c|c|}
\hline $\begin{array}{c}\text { k- } \\
\text { Fold }\end{array}$ & Data Latih & Data Uji & Accuracy & Precision & Recall \\
\hline 2 & 100 & 100 & $80,50 \%$ & $79,28 \%$ & $84,00 \%$ \\
\hline 4 & 150 & 50 & $84,00 \%$ & $84,82 \%$ & $83,00 \%$ \\
\hline 5 & 160 & 40 & $83,00 \%$ & $85,79 \%$ & $80,00 \%$ \\
\hline 8 & 175 & 25 & $86,00 \%$ & $87,38 \%$ & $85,02 \%$ \\
\hline 10 & 180 & 20 & $84,00 \%$ & $85,95 \%$ & $83,00 \%$ \\
\hline & \multicolumn{2}{|c|}{ Rata-rata } & $83,50 \%$ & $84,64 \%$ & $83,00 \%$ \\
\hline
\end{tabular}

Tabel 4 menunjukkan bahwa kenaikan $k$-Fold pada $k$-Fold Cross Validation pada seleksi fitur TF-IDF tidak berpengaruh pada kenaikan hasil nilai accuracy. Pada precision, nilai mengalami kenaikan dari dari $k$-Fold $=2$ menuju $k$-Fold $=8$. Selanjutnya precision mengalami penuruan dari $k$-Fold $=8$ menuju $k$-Fold $=10$. Pada recall penurunan terjadi dari $k$-Fold $=2$ hingga $k$-Fold $=5$, setelah itu sempat mangalami kenaikan pada $k$-Fold $=8$ dan kembali menurun pada $k$-Fold $=10$. Pada seleksi fitur TF-IDF, accuracy tertinggi $86,00 \%$ terjadi pada $k$-Fold $=8$. Precision tertinggi $87,38 \%$ terjadi pada $k$-Fold $=8$. Sedangkan, recall tertinggi $85,02 \%$ terjadi pada $k$-Fold $=8$. Nilai rata-rata seleksi fitur $T F-I D F$ adalah: accuracy $=83,50 \%$, precision $=$ $84,64 \%$, dan recall $=83,00 \%$. 


\section{KESIMPULAN DAN SARAN}

Kesimpulan pada penelitian ini adalah bahwa algoritma $S V M$ dengan perbandingan dua seleksi fitur dan variabel $k$-Fold pada Cross Validation menghasilkan evaluasi yang cukup baik digunakan untuk analisis sentimen dengan perolehan nilai tertinggi accuracy dan recall pada kedua seleksi bernilai sama. Sedangkan khusus precision tertinggi pada hasil dari seleksi fitur $T F$ $I D F$. Opini masyarakat setelah pernyataan Mendikbud dan hasil penelitian yang sudah dipublikasikan sebelum pernyataan Mendikbud hampir memiliki kesamaan kata dan makna. Dengan demikian dari hasil penelitian ini, kata gratis, mandiri, dan waktu dapat mewakili masyarakat sebagai pernyataan sentimen positif. Sementara itu, kata permanen, hp dan sosialisasi dapat mewakili masyarakat sebagai pernyataan sentimen negatif. Kenaikan nilai $k$-Fold pada $k$ Fold Cross Validation tidak berbanding lurus dengan kenaikan nilai ketiga evaluasi baik pada Term Frequency maupun $T F-I D F$. Ini berarti khususnya penelitian ini, kenaikan jumlah data latih terhadap data uji tidak mempengaruhi kenaikan hasil nilai evaluasi. Sedangkan mengenai hasil pada nilai $k$-Fold yang sama, tidak selalu memperoleh hasil nilai evaluasi yang sama. Namun demikian, walaupun terjadi fluktuasi dan perbedaan nilai hampir pada setiap $k$-Fold, ada kesamaan pada kedua seleksi fitur bahwa 8-Fold Cross Validation memberikan hasil nilai evaluasi tertinggi pada accuracy, precision, dan recall.

Saran untuk penelitian selanjutnya adalah bahwa masih terbukanya ruang yang lebar untuk melakukan penelitian analisis sentimen sehubungan dengan banyaknya cara untuk melakukan pre-processing, seleksi fitur, permodelan, dan evaluasi. Lebih dari itu, ruang lingkup untuk obyek penelitan analisis sentimen masih merupakan area yang tidak terbatas untuk diteliti.

\section{DAFTAR PUSTAKA}

[1] Somantri, O., \& Apriliani, D., 2018, Support Vector Machine Berbasis Feature Selection untuk Sentiment Analysis Kepuasan Pelanggan Terhadap Pelayanan Warung dan Restoran Kuliner Kota Tegal, Jurnal Teknologi Informasi dan Ilmu Komputer, Vol. 5, Ed. 5, Hal. $537-$ 548.

[2] Irfani, F. F., Triyanto, M., \& Hartanto, A. D., 2020, Analisis Sentimen Review Aplikasi Ruangguru Menggunakan Algoritma Support Vector Machine, JBMI (Jurnal Bisnis, Manajemen, dan Informatika), Vol. 16, Ed. 3, Hal. 258-266.

[3] Kirilenko, A. P., Stepchenkova, S. O., Kim, H., \& Li, X., 2018, Automated sentiment analysis in tourism: Comparison of approaches, Journal of Travel Research, Vol. 57, Ed. 8, Hal. 1012-1025.

[4] Natasuwarna, A. P., 2019, Analisis Sentimen Keputusan Pemindahan Ibukota Negara Menggunakan Klasifikasi Naive Bayes, SENSITIf: Seminar Nasional Sistem Informasi dan Teknologi Informasi, Makasar, December 16-17.

[5] Fiarni, C., Maharani, H., \& Pratama, R., 2016, Sentiment analysis system for Indonesia online retail shop review using hierarchy Naive Bayes technique, In 2016 4th international conference on information and communication technology (ICoICT), IEEE, Bandung, May 25.

[6] Hasanah, A., Lestari, A. S., Rahman, A. Y., \& Daniel, Y. I., 2020, Analisis aktivitas belajar daring mahasiswa pada pandemi Covid-19, KTI masa WFH LP2M UIN Sunan Gunung Djati, Hal. 1-9.

[7] Fitriyani, Y., Fauzi, I., \& Sari, M. Z., 2020, Motivasi Belajar Mahasiswa Pada Pembelajaran Daring Selama Pandemik Covid-19, Jurnal Kependidikan: Jurnal Hasil Penelitian dan Kajian Kepustakaan di Bidang Pendidikan, Pengajaran dan Pembelajaran, Vol. 6, Ed. 2, Hal. 165-175.

[8] Dewi, W.A.F., 2020, Dampak Covid-19 terhadap Implementasi Pembelajaran Daring di Sekolah Dasar, Edukatif: Jurnal Ilmu Pendidikan, Vol. 2, Ed. 1, Hal. 55-61.

[9] Arianto, B. W., \& Anuraga, G., 2020, Topic Modeling for Twitter Users Regarding the" 
Ruanggguru" Application, Jurnal ILMU DASAR, Vol. 21, Ed. 2, Hal. 149-154.

[10] Sadikin, A., \& Hamidah, A., 2020, Pembelajaran Daring di Tengah Wabah Covid19. BIODIK, Vol. 6, Ed. 2, Hal. 109-119.

[11] Jamaluddin, D., Ratnasih, T., Gunawan, H., \& Paujiah, E., 2020, Pembelajaran daring masa pandemik Covid-19 pada calon guru: hambatan, solusi dan proyeksi, LP2M UIN Sunan Gunung Djati Bandung.

[12] Buntoro, G.A., 2017, Analisis Sentimen Calon Gubernur DKI Jakarta 2017 Di Twitter, INTEGER: Journal of Information Technology, Vol. 2, Ed. 1.

[13] Yanti, W.N., 2018, Analisis Sentimen Media Sosial (Twitter) terhadap Layanan Provider Telekomunikasi (Telkomkel) Menggunakan Metode Multinomial Naive Bayes, Skripsi, Fakultas Sains dan Teknologi, Universitas Islam Negeri Maulana Malik Ibrahim, Malang.

[14] Tyagi, P., \& Tripathi, R. C., 2019, A Review towards the Sentiment Analysis Techniques for the Analysis of Twitter Data, International Conference on Advanced Computing and Software Engineering 2019, February 8.

[15] Pamungkas, D. S., Setiyanto, N. A., \& Dolphina, E, 2015, Analisis Sentiment pada Sosial Media Twitter Menggunakan Naïve Bayes Classifier terhadap Kata Kunci "Kurikulum 2013", Techno. Com, Vol. 14, Ed. 4, Hal. 299-314.

[16] Perdana, R.S., 2018, Penerapan Sentimen Analisis Acara Televisi Pada Twitter Menggunakan Support Vector Machine dan Algoritma Genetika sebagai Metode Seleksi Fitur, Jurnal Pengembangan Teknologi Informasi dan Komputer e-ISSN, 2548, 964X.

[17] Hidayatullah, A. F., \& Azhari, A. S., 2015, Analisis sentimen dan klasifikasi kategori terhadap tokoh publik pada twitter, In Seminar Nasional Informatika (SEMNASIF), July 9.

[18] Antinasari, P., Perdana, R. S., \& Fauzi, M. A., 2017, Analisis Sentimen Tentang Opini Film Pada Dokumen Twitter Berbahasa Indonesia Menggunakan Naive Bayes Dengan Perbaikan Kata Tidak Baku, Jurnal Pengembangan Teknologi Informasi dan Ilmu Komputer eISSN, 2548, 964X.

[19] Fanissa, S., Fauzi, M. A., \& Adinugroho, S., 2018, Analisis Sentimen Pariwisata di Kota Malang Menggunakan Metode Naive Bayes dan Seleksi Fitur Query Expansion Ranking, Jurnal Pengembangan Teknologi Informasi dan Ilmu Komputer e-ISSN, 2548, 964X.

[20] Mihuandayani, M., Feriyanto, E., Syarham, S., \& Kusrini, K., 2018, Opinion Mining pada Komentas Twitter E-KTP Menggunakan Naïve Bayes Classier, Semnasteknomedia Online, Vol.6, Ed. 1, Hal. 1-2.

[21] Irfani, F.F., Triyanto, M., Hartanto, A.D., Kusnawi, 2020, Analisis Sentimen Review Aplikasi Ruang Guru Menggunakan Algoritm Support Vector Machine, Jurnal Business, Management, dan Informatika, Vol. 16, Ed. 3, Hal. 258-266.

[22] Hidayat, A. N., 2015, Analisis Sentimen Terhadap Wacana Politik Pada Media Masa Online Menggunakan Algoritma Support Vector Machine Dan Naive Bayes, Jurnal Elektronik Sistem Informasi dan Komputer, Vol. 1, Ed. 1, Hal. 12-18.

[23] Rofiqoh, U., Perdana, R. S., \& Fauzi, M. A., 2017, Analisis Sentimen Tingkat Kepuasan Pengguna Penyedia Layanan Telekomunikasi Seluler Indonesia Pada Twitter Dengan Metode Support Vector Machine dan Lexicon Based Features, Jurnal Pengembangan Teknologi Informasi dan Ilmu Komputer e-ISSN, 2548, 964X.

[24] Santoso, V.I., Virginia, G., Lukito, Y., 2017, Penerapan Sentiment Analysis pada Hasil Evaluasi Dosen dengan Metode Support Vector Machine, Jurnal Transformatika, Vol. 14, Ed. 2, Hal. 72-7.

[25] Hikmawan, S., Pardamean, A., Khasanah, S.N., 2020, Sentimen Analisis Publik Terhadap Joko Widodo Terhadap Wabah Covid-19 Menggunakan Metode Machine Learning. Jurnal Kajian Ilmiah, Vol. 20, Ed. 2, Hal. 167-176.

[26] Aggarwal, C. C., 2015, Data mining: the textbook, Springer. 